\title{
Effects of Post-Deposition Annealing Temperatures on the Composition of Interfacial Layer at Germanium $(\mathrm{Ge})$ /Aluminium Oxide $\left(\mathrm{Al}_{2} \mathrm{O}_{3}\right)$ \\ (Kesan Suhu Penyepuhlindapan Pasca Pemendapan ke atas Komposisi Antara Muka Lapisan Oksida Germanium (Ge)/Aluminium $\left(\mathrm{Al}_{2} \mathrm{O}_{3}\right)$ )
}

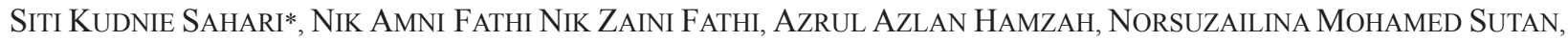 \\ Zaidi Embong, Suhana MoHamed Sultan, MuHammad Kashif, Marini SaWAWI, Lilik Hasanah, \\ RoHANA SAPAWI, KURYATI KIPLI, ABDUl RAHMAN KRAM\& NAZREEN JUNAIDI
}

\section{ABSTRACT}

The understanding of chemical bonding structure of high $k$ dielectrics/Germanium (Ge) interface is upmost importance in order to form a good quality dielectric/Ge interface in fabricating Ge metal oxide semiconductor field effect transistor (MOSFETS). In addition, there is still no detail explanation on the interfacial growth of dielectrics/Ge under the influenced of different temperature of post deposition anneal. In current work, the effects of post deposition anneal (PDA) temperature between $400^{\circ} \mathrm{C}$ and $600^{\circ} \mathrm{C}$ on the chemical composition of interfacial layer between Ge and $\mathrm{Al}_{2} \mathrm{O}_{3}$ were examined by X-ray photoelectron spectroscopy (XPS). Investigation on thermal stability and structural characteristics for gate structure of $\mathrm{Al}_{2} \mathrm{O}_{3}$ dielectric grown on Ge by $\mathrm{RF}$ sputtering was done by analyzing X-ray photoelectron spectroscopy (XPS) spectra. It is observed that the oxygen deficient region in interfacial layer (IL) is enhanced rather than fully oxidized $\mathrm{Al}_{2} \mathrm{O}_{3}$ with increased PDA temperatures. These undesired phenomena caused shrinkage of IL at Ge/Al $\mathrm{O}_{3}$ interface at higher temperature of $600^{\circ} \mathrm{C}$.

Keywords: $\mathrm{Al}_{2} \mathrm{O}_{3}$; germanium; interfacial layer; post deposition anneal

\section{ABSTRAK}

Pemahaman tentang struktur ikatan kimia yang tinggi dielektrik/antara muka Germania (Ge) adalah sangat penting untuk membentuk antara muka dielektrik/Ge berkualiti baik dalam fabrikasi Ge kesan medan transistor logam oksida semikonduktor (MOSFETS). Di samping itu, masih belum ada penjelasan terperinci mengenai pertumbuhan antara dielektrik/Ge di bawah pengaruh suhu yang berlainan bagi pemanasan pasca sepuh lindap. Penyelidikan kesan suhu pemendapan pasca sepuh lindap (PDA) antara $400^{\circ} \mathrm{C}$ dan $600^{\circ} \mathrm{C}$ pada komposisi kimia lapisan antara antara Ge dan $\mathrm{Al}_{2} \mathrm{O}_{3}$ diperiksa oleh spektroskopi fotoelektron x-ray (XPS). Dalam makalah ini, kami mengkaji kestabilan terma dan pencirian struktur untuk struktur gerbang $\mathrm{Al}_{2} \mathrm{O}_{3}$ dielektrik yang ditanam di Ge oleh percikan $\mathrm{RF}$ oleh spektroskopi fotoelektron $x$-ray (XPS). Difahamkan bahawa rantau kekurangan oksigen dalam lapisan antara muka (IL) ditingkatkan daripada $\mathrm{Al}_{2} \mathrm{O}_{3}$ sepenuhnya teroksida dengan suhu PDA yang meningkat. Fenomena yang tidak diingini ini menyebabkan pengecutan IL pada antara muka $\mathrm{Ge} / \mathrm{Al}_{2} \mathrm{O}_{3}$ pada suhu lebih tinggi $600^{\circ} \mathrm{C}$.

Kata kunci: $\mathrm{Al}_{2} \mathrm{O}_{3}$; Ge; lapisan antara muka; pos pemendapan rawatan haba

\section{INTRODUCTION}

Germanium $(\mathrm{Ge})$ can be used to replace Silicon $(\mathrm{Si})$ as a channel because it has four times higher hole mobility and two times higher electron mobility than Si (Wallace et al. 2009). The replacement of Si by Ge reopens the space for high-k dielectric Ge metal oxide semiconductor field effects transistors (MOSFETs) development. However, besides fabrication handling of Ge as a channel, the quality of the surface and interface between high $\mathrm{k}$ and $\mathrm{Ge}$ is still a main technological issue that must be overcome for development of MOSFETs. The poor quality of Ge/dielectrics with high interface states density and high interface roughness have been shown on the high permittivity dielectrics such as $\mathrm{HfO}_{2}$, $\mathrm{ZrO}_{2}$, on Ge substrate (Han et al. 2013; Ngai et al. 2000;
$\mathrm{Wu}$ et al. 2005). Therefore, to improve the quality of interface between high $\mathrm{k}$ and $\mathrm{Ge}$, the implementation of IL between high $\mathrm{k}$ and Ge has been proposed (Shang et al. 2007). For the case of Aluminum oxide $\left(\mathrm{Al}_{2} \mathrm{O}_{3}\right)$, the formation of interfacial layer $\left(\mathrm{GeO}_{\mathrm{x}}\right)$ between $\mathrm{Ge}$ and $\mathrm{Al}_{2} \mathrm{O}_{3}$ resulted in low defect states density $\left(10^{-11} \mathrm{~cm}^{-3}\right)$ (Zhang et al. 2013). To resolve the issues of surface and interface between high $\mathrm{k}$ and $\mathrm{Ge}$, the selection of annealing ambience during the fabrication is to be taken into account. Previous research showed that the selective passivation of low interface traps can be influenced under multiple conditions of annealing (Zhang et al. 2015). In addition, surface treatment with $\mathrm{HBr}, \mathrm{HCl}, \mathrm{HF}, \mathrm{H}_{2} \mathrm{~S}$-based have been used to obtain a well passivated at $\mathrm{Ge}$ and high $\mathrm{k}$ interface (Bai-Qing et al. 2012; Elshochta et. al. 2006). 
In our previous study, we have shown that the Chlorine (Cl) termination after $\mathrm{HCl}$ treatment on $\mathrm{Ge}$ surface was confirmed by $\mathrm{Cl} 2 \mathrm{p}$ spectra of XPS measurement and this can prevent slightly the intermixing between $\mathrm{Ge}$ and $\mathrm{Al}_{2} \mathrm{O}_{3}$ after PDA of $400^{\circ} \mathrm{C}$ (Sahari et al. 2017b, 2017a). In this study, we continue the study by investigating on the effect of $\mathrm{Cl}$ - termination by increasing the temperature up to $600^{\circ} \mathrm{C}$. This study aims to observe the evolution process of formation intermixing during post deposition anneal of $\mathrm{Al}_{2} \mathrm{O}_{3}$ on $\mathrm{Ge}$ substrate. This was accomplished by monitoring the growth of suboxides components as a function of post deposition anneals temperatures.

In this work, thickness of interfacial layer between $\mathrm{Ge}$ and $\mathrm{Al}_{2} \mathrm{O}_{3}$ was measured using FESEM. The x-ray photoelectron spectroscopy (XPS) was performed to measure the chemical composition of IL.

\section{MATERIALS AND METHODS}

In this work, p-type Ge wafers with surface orientation (100) with resistivity $0.001-10 \mathrm{ohm} / \mathrm{cm}$ were used. The cleaning process is similar with the previous study (Sahari et al. 2015, 2014). First, the wafers were cleaned with deionized water before dipped in $15 \%$ hydrogen peroxide $\left(\mathrm{H}_{2} \mathrm{O}_{2}\right)$. After that, the wafers were rinsed with deionized water and subsequently dipped in $30 \%$ hydrochloric $(\mathrm{HCl})$ acid. The final step of cleaning method is dipping the wafers in deionized water. Then, the $\mathrm{Al}_{2} \mathrm{O}_{3}$ layer was deposited on cleaned Ge wafer by RF sputtering at $250 \mathrm{~W}$ with pure Argon flow of $20 \mathrm{sccm}$, and the partial pressure of chamber was maintained at 24 mTorr during the sputtering process. The deposition time was $2 \mathrm{~min}$. After that, post deposition anneals (PDA) were performed at temperature ranges between $400^{\circ} \mathrm{C}$ and $600^{\circ} \mathrm{C}$ for $30 \mathrm{~min}$ in a furnace with flowing $\mathrm{N}_{2}$ at a rate of $5 \mathrm{~L} / \mathrm{min}$ under atmospheric pressure. The composition of IL was characterized by $\mathrm{x}$-ray photoelectron spectroscopy (XPS) at take-off angle $0^{\circ}$ and $15^{\circ}$ with an Alk $\alpha$ radiation source operating at 1486.6 $\mathrm{eV}$. The thickness of IL was evaluated by XPS from the measured intensity ratio Ge metal $3 \mathrm{~d} / \mathrm{Ge}$ (oxide) $3 \mathrm{~d}$ with considering the escape depth of $2.3 \mathrm{~nm}$ for Alka.

\section{RESULTS AND DISCUSSION}

Figure 1 shows the post deposition anneal temperature dependence of IL thickness. The thickness of IL between $\mathrm{Ge}$ and $\mathrm{Al}_{2} \mathrm{O}_{3}$ increases upon increasing the post deposition anneal temperature up to $550^{\circ} \mathrm{C}$. However, it decreases when the PDA temperature increased to $600^{\circ} \mathrm{C}$. This result is consistent with the previous report that showed the shrinkage of IL at Ge/HfN interface after high annealing temperature in nitrogen ambience may be caused by bond breaking in the IL which leads to $\mathrm{GeO}$ desorption or densification of IL during high PDA temperature (Ching et al. 2006). To investigate the phenomena in detail, we evaluated the chemical bonding structure between $\mathrm{Ge}$ and $\mathrm{Al}_{2} \mathrm{O}_{3}$ with PDA temperature dependence as shown in Figure 2. In the figure, Ge $3 \mathrm{~d}$ of $2 \mathrm{~min}$ Ge thermal oxidation is shown as a reference. It is observed that the binding energy originated from Ge oxide peak at $33.2 \mathrm{eV}$, separated by $3.4 \mathrm{eV}$ from $\mathrm{Ge} 3 \mathrm{~d}_{5 / 2}$ metal, originated from $\mathrm{Ge}$ bound to oxygen. This binding energy was shifted to lower binding energy after deposition of $\mathrm{Al}_{2} \mathrm{O}_{3}$. It may be attributed to the non-uniform reaction that affects the formation of oxygen vacancies and caused defects during sputtering as reported in previous work for Silicon substrate (He et al. 2005). Moreover, after PDA was performed, this oxidized peak is shifted slightly to higher binding energy corresponds to the changes of chemical composition at IL. With increasing of PDA temperature up to $550^{\circ} \mathrm{C}$, no changes are observed on the binding energy difference between Ge metal and Ge oxide peak. However, after PDA at $600^{\circ} \mathrm{C}$, the energy separation between $\mathrm{Ge}$ metal and $\mathrm{GeO}_{2}$ decreases to $2.5 \mathrm{eV}$. This result may be attributed to the $\mathrm{GeO}_{\mathrm{x}}$ undergo different structural rearrangement under $\mathrm{N}_{2}$ annealing that produce different intermediate phases before ultimately turning into metallic Ge (Zhao et al. 2015).

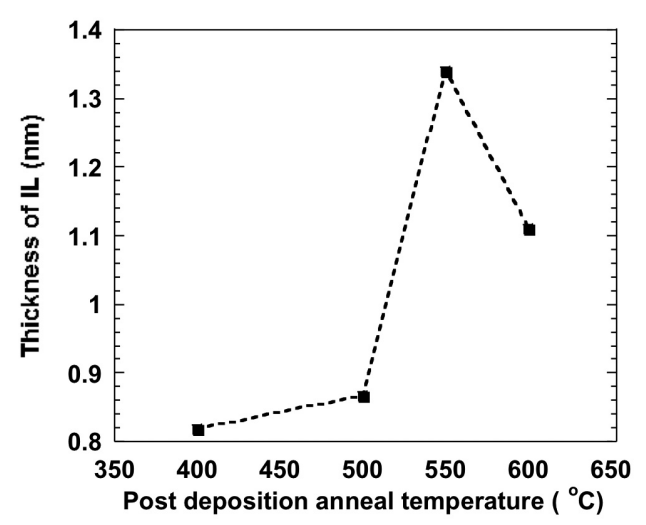

FIGURE 1. Thickness of interfacial layer at different post deposition anneal temperature

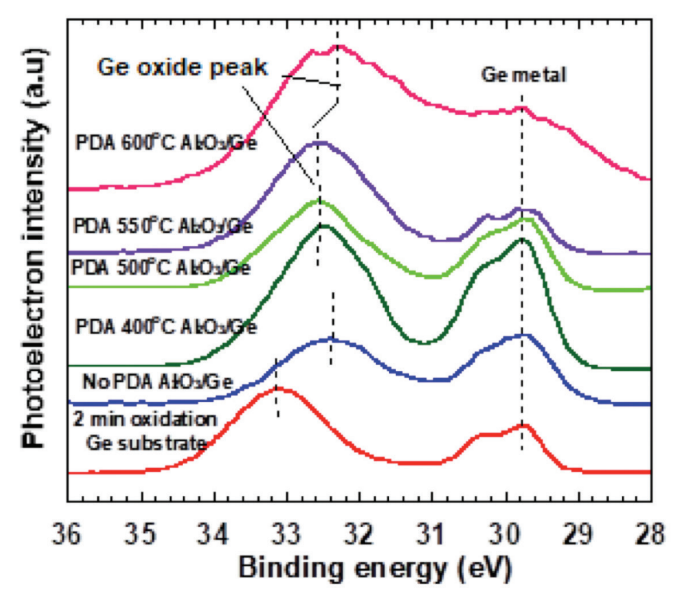

FIGURE 2. Ge $3 \mathrm{~d}$ spectra of $\mathrm{Al}_{2} \mathrm{O}_{3} / \mathrm{Ge}$ at post deposition anneal between $400^{\circ} \mathrm{C}$ and $600^{\circ} \mathrm{C}$

To observed the composition of IL between Ge and $\mathrm{Al}_{2} \mathrm{O}_{3}$ in detail, the Ge $3 \mathrm{~d}$ spectra were divided into 5 components; $\mathrm{Ge} \mathrm{d}_{5 / 2}$ and $\mathrm{Ge} 3 \mathrm{~d}_{3 / 2}\left(\mathrm{Ge}^{0+}\right)$ for metal, 
suboxides $\left(\mathrm{Ge}^{1+}, \mathrm{Ge}^{2+}, \mathrm{Ge}^{3+}\right)$ and $\mathrm{GeO}_{2}\left(\mathrm{Ge}^{4+}\right)$ using Shirley background and 6 Gaussian peaks as shown in Figure 3. The interval of the peak energies for each component of suboxides components was set to $0.8 \mathrm{eV}$ as similar with the reported values for $\mathrm{GeO}_{2} / \mathrm{Ge}$ interface (Lucovsky et al. 2013; Matsui et al. 2011; Schmeisser et al. 1986; Shiyabama et al. 2014). The existent of the Ge suboxide components indicates the formation of chemical bond between $\mathrm{Ge}-\mathrm{O}$ and $\mathrm{Ge}-\mathrm{Al} / \mathrm{Ge}$ between thin film and $\mathrm{Ge}$ substrate (He et al. 2016). From the figure, it shows the intensity of $\mathrm{Ge}^{2+}, \mathrm{Ge}^{3+}$ and $\mathrm{Ge}^{4+}$ increases with increasing PDA temperature between $400^{\circ} \mathrm{C}$ and $550^{\circ} \mathrm{C}$. The percentage of $\mathrm{Ge}^{3+}$ and $\mathrm{Ge}^{4+}$ increased almost $50 \%$ when PDA temperature is increased from $400^{\circ} \mathrm{C}$ to $550^{\circ} \mathrm{C}$. These results indicate the existence of the oxidation phenomena at the surface of Ge substrates. On the other hand, for the case of PDA at $600^{\circ} \mathrm{C}$, the peak intensity of $\mathrm{Ge}^{4+}$ and $\mathrm{Ge}^{3+}$ were decreased. In addition, it is observed that the peak intensity of $\mathrm{Ge}^{3+}$ component is larger than $\mathrm{Ge}^{4+}$ for the PDA temperature between 400 and $550^{\circ} \mathrm{C}$. By taking consideration of electronegativity $\mathrm{Ge}(\chi \mathrm{Ge}=2.0$, Al-Germanate peak is expected to appear around $\mathrm{Ge}^{3+}$ component (Song et al. 2007). The peak for $\mathrm{Ge}^{3+}$ might thus include Al-Germanate component. These results indicate that the Al-Germanate increased with increasing PDA temperature.

The O1s core level spectra shown in Figure 4 are evaluated to examine the nature of oxide formed on
Germanium. Before sputtering, the O1s peak substrate present only at $532.5 \mathrm{eV}$, corresponding to the binding energy of native $\mathrm{GeO}_{2}$. After $\mathrm{Al}_{2} \mathrm{O}_{3}$ deposited on $\mathrm{Ge}$ substrate, the peak of O1s shifts to $531.3 \mathrm{eV}$. This peak shifting suggested that the formation of interfacial oxide or the formation of germinate by the reaction between $\mathrm{Al}_{2} \mathrm{O}_{3}$ and $\mathrm{GeO}_{2}$ on Ge surface. From Gibbs free energy, these two processes have the possibility to take place. With increasing temperature from $400^{\circ} \mathrm{C}$ to $550^{\circ} \mathrm{C}$, this peak keeps shifted towards higher binding energy and fixed at $532 \mathrm{eV}$. According to Wang and Mayer (1998), oxygen deficient oxide has higher binding energy than that of fully oxidized metal oxide. Therefore, according to the XPS result, non-uniform reaction occurs during sputtering which results in the formation of oxygen vacancies and defect. By increasing the annealing temperature, the oxygen deficient region and intermixing are enhanced. The further increased of IL for the PDA temperature up to $550^{\circ} \mathrm{C}$ indicates the additional Al-germinate layer after high temperature processing.

The shrinkage of IL after $600^{\circ} \mathrm{C}$ is still in question. Therefore, Angle Resolved XPS (ARXPS) for Ge3d was conducted to allow us to investigate the decreasing of IL thickness after very high PDA temperature at $600^{\circ} \mathrm{C}$. Figure 5 shows the ARXPS at takeoff angle 0 and $15^{\circ}$. The intensity was normalized with the signal originated by $\mathrm{Ge}$ metal. The ARXPS indicates that the ratio of Ge suboxides $\left(\mathrm{Ge}^{1+}-\mathrm{Ge}^{3+}\right)$ intensity to Ge metal intensity increased as
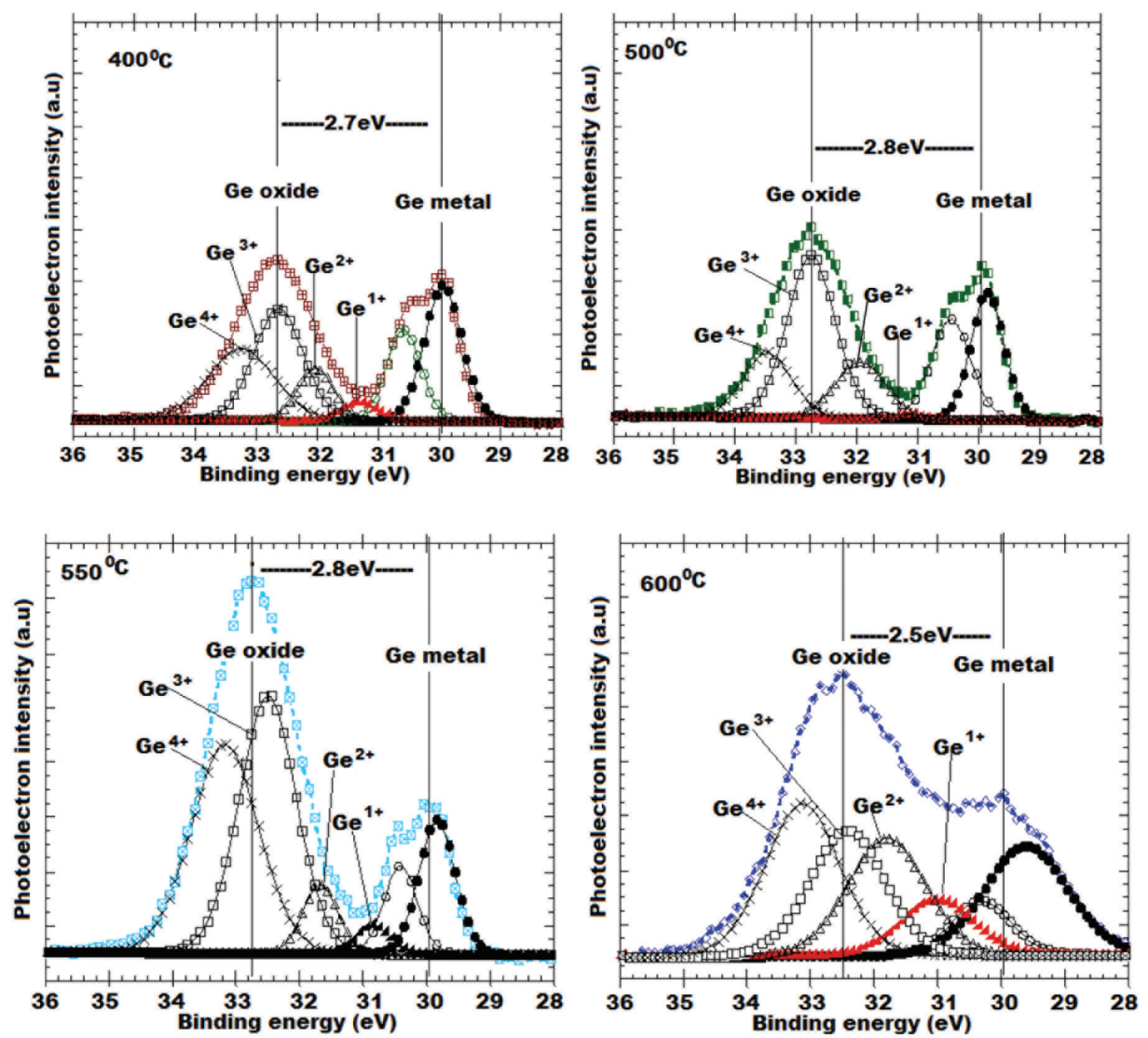

FIGURE 3(a). Evolution of Ge 3d with PDA dependence 


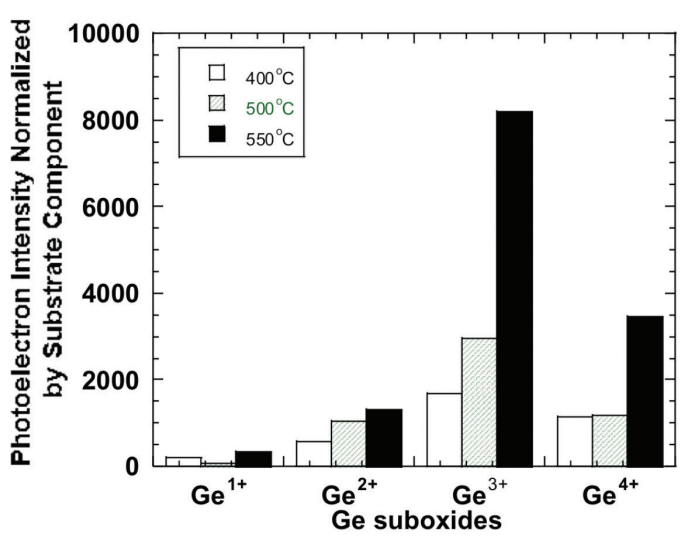

FIGURE 3(b). Ge oxide components on PDA temperatures dependence

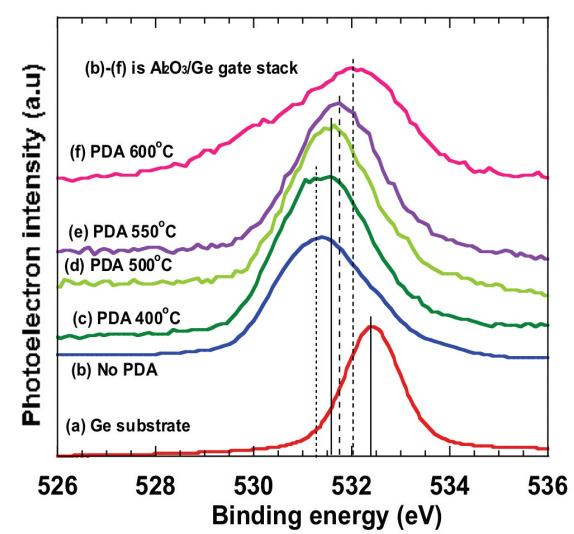

FIGURE 4. O1s signal at different PDA temperature between 400 and $600^{\circ} \mathrm{C}$

take-off angle was getting smaller, which means that $\mathrm{GeO}_{x}$ at the upper portion of gate dielectric $\left(\mathrm{Al}_{2} \mathrm{O}_{3}\right)$. This result is inconsistent with Shibayama et al. (2014) where they reported that only $\mathrm{Ge}^{3+}$ and $\mathrm{Ge}^{4+}$ on the upper portion of $\mathrm{Al}_{2} \mathrm{O}_{3}$. The inconsistency of these results may be caused by different PDA temperatures of these works. There are two possible mechanisms involved in the $\mathrm{GeO}_{2}$ incorporation into $\mathrm{Al}_{2} \mathrm{O}_{3}$ thin film. First is the diffusion of $\mathrm{Ge}$ atom from dissociated IL or substrate itself which is then oxidized with the residual oxygen, second is the oxidation of volatile $\mathrm{GeO}$. From these results, we believe that the outdiffusion occurred during PDA $\mathrm{Ge} / \mathrm{Al}_{2} \mathrm{O}_{3}$ gate stack and enhanced with the increasing of PDA temperatures. Thus, the dissociation of the IL is believed to be the real cause of shrinkage of IL thickness with increasing temperatures because the detection of $\mathrm{GeO}_{2}$ within the bulk of gate dielectric.

\section{CONCLUSION}

The PDA temperatures dependence on the chemical composition of IL between $\mathrm{Al}_{2} \mathrm{O}_{3}$ and $\mathrm{Ge}$ has been studied. The results conclude that the formation of $\mathrm{Ge}^{3+}$ is enhanced with the PDA temperature up to $550^{\circ} \mathrm{C}$ while $\mathrm{Ge}^{4+}$ is

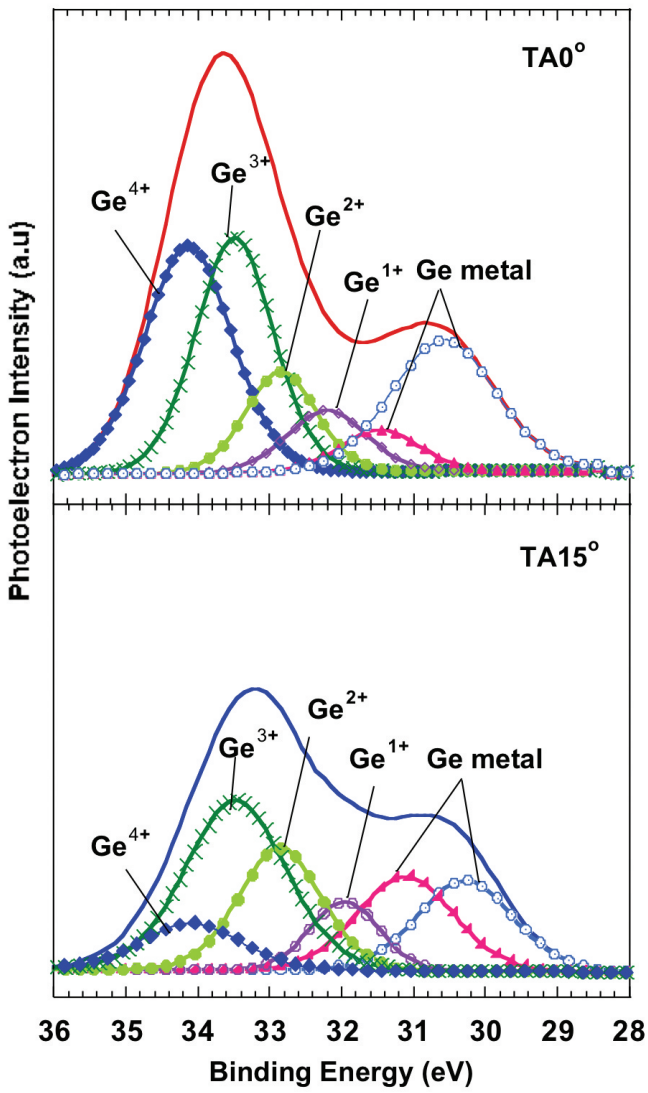

FIGURE 5. Angle resolve XPS of Ge $3 \mathrm{~d}$ spectrum of $\mathrm{Al}_{2} \mathrm{O}_{3} / \mathrm{Ge}$ stack after PDA at $600^{\circ} \mathrm{C}$

dominated during PDA at $600^{\circ} \mathrm{C}$. The higher formation of $\mathrm{Ge}^{3+}$ is related to the formation of Al-germinate while the formation of $\mathrm{Ge}^{4+}$ is thought related to the re-oxidation when the temperature of PDA is increased. The shrinkage of IL after PDA of $600^{\circ} \mathrm{C}$ is related to the $\mathrm{GeO}$ desorption process. As PDA temperature increased, more $\mathrm{GeO}_{2}$ is incorporated in $\mathrm{Al}_{2} \mathrm{O}_{3}$ and severe desorption of IL occurs at $\mathrm{Al}_{2} \mathrm{O}_{3} / \mathrm{Ge}$ gate stack. As the overall results, it can be concluded that the $\mathrm{Cl}$-termination of $\mathrm{Ge}$ surface is unstable and cannot prevent the intermixing between $\mathrm{Ge}$ and $\mathrm{Al}_{2} \mathrm{O}_{3}$ as the PDA temperature increased up to $600^{\circ} \mathrm{C}$. Therefore, the continuous optimization of interface structure through process modification can improve the quality of interface between $\mathrm{Al}_{2} \mathrm{O}_{3}$ and $\mathrm{Ge}$.

\section{ACKNOWLEDGEMENTS}

The authors would like to acknowledge Universiti Malaysia Sarawak (UNIMAS) and the Ministry of Education (Malaysia) for supporting this work under FRGS/ TK04(02)/1082/2013(28) and F02/FRGS/1617/2017.

\section{REFERENCES}

Bai-Qing, X., Hu-Dong, C., Bing, S., Sheng-Kai, W. \& HongGang, L. 2012. The impact of $\mathrm{HCl}$ precleaning and sulfur passivation on the $\mathrm{Al}_{2} \mathrm{O}_{3} / \mathrm{Ge}$ interface in Ge metal-oxidesemiconductor capacitors. Chinese Physics Letters 29(4): 046801. 
Ching, C.C., Hsin, C.C., Chen, W.C., Lu, H.S., Yang, H.C. \& Chang, Y.C. 2006. Effects of postdeposition annealing on the characteristics of HfOxNy dielectrics on germanium and silicon substrates. Journal of The Electrochemical Society 153(7): F160-F168.

Han, J.H., Zhang, R., Osada, T., Hata, M., Takenaka, M. \& Takagi, S. 2013. Impact of plasma post-nitridation on HfO2/ $\mathrm{Al} 2 \mathrm{O} 3 / \mathrm{SiGe}$ gate stacks toward EOT scaling. Microelectronic Engineering 109: 266-269.

He, G., Zhang, J., Sun, Z., Lv, J., Chen, H. \& Liu, M. 2016. Evolution of interface chemistry and dielectric properties of $\mathrm{HfO} 2 / \mathrm{Ge}$ gate stack modulated by $\mathrm{Gd}$ incorporation and thermal annealing. AIP Advances 6: 025003-1-025003-7.

He, G., Liu, M., Zhu, L.Q., Chang, M., Fang, Q. \& Zhang, L.D. 2005. Effect of postdeposition annealing on the thermal stability and structural characteristics of sputtered $\mathrm{HfO} 2$ films on Si (1 00 ). Surface Science 576: 67-75.

Lucovsky, G., Kim, J.W. \& Nordlund, D. 2013. First demonstration of device-quality symmetric N-MOS and P-MOS capacitors on p-type and n-type crystalline Ge substrates. Microelectron. Eng. 109: 370-373.

Matsui, M., Murakami, H., Fujioka, T., Ohta, A., Higashi, S. \& Miyazaki, S. 2011. Characterization of chemical bonding features at metal/GeO2 interfaces by X-ray photoelectron spectroscopy. Microelectron. Eng. 88(7): 1549-1552.

Sahari, S.K., Kashif, M., Mohamed Sutan, N., Embong, Z., Nik Zaini Fathi, N.A.F., Hamzah, A.A., Yeop Majlis, B. \& Ahmad, I. 2017a. Growth kinetic and composition of the interfacial layer for $\mathrm{RF}$ sputtering $\mathrm{Al}_{2} \mathrm{O}_{3}$ layer on germanium. Microelectronics International 34(2): 64-68.

Sahari, S.K., Kashif, M., Sawawi, M., Fathi, N.A.F.N.Z., Hamzah, A.A., Majlis, B.Y., Junaidi, N., Sapawi, R., Kipli, K., Mohamed Sutan, Abdul Halim, N.A. \& Wan Masra, S.M. 2017b. Stability of chlorine termination on $\mathrm{Ge}(100)$ and $\mathrm{Ge}(111)$ surfaces. MATEC Web of Conferences 05005: 1-5.

Sahari, S.K., Fathi, N.A.F.N.Z., Sutan, N.M., Sapawi, R., Hamzah, A.A.B. \& Majlis, B.Y. 2015. Wet chemical cleaning effect on the formation of ultrathin interfacial layer between germanium $(\mathrm{Ge})$ and high-k dielectric. IEEE Regional Symposium on Micro and Nano Electronics 15664934.

Sahari, S.K., Momamad Sutan, N., Sapawi, R., Yakub, I., Awg Salleh, D.N.S. \& Lit, A. 2014. Defects generation in Ge/ $\mathrm{GeO} 2$ structure. Key Engineering Materials 594: 1069-1073.

Schmeisser, D., Schnell, R.D., Bogen, A., Himpsel, F.J., Rieger, D., Landgren, G. \& Morar, J.F. 1986. Surface oxidation states of germanium. Surf. Sci. 172: 455-465.

Shang, H., Frank, M.M., Gusev, A.P., Chu, J.O., Bedell, S.W., Guarini, K.W. \& Leong, M. 2007. Germanium channel MOSFETs: Opportunities and challenges. IBM Journal of Research and Development 50: 377-386.

Shibayama, S., Kato, K., Sakashita, M., Takeuchi, W., Taoka, N., Nakatsuka, O. \& Zaima, S. 2014. Thin Solid Films 557: 282-287.

Song, J., Kakushima, K., Ahmet, P., Tsutsui, K., Sugii, N., Hattori, T. \& Iwai, H. 2007. Improvement of interfacial properties with interfacial layer in La2O3/Ge structure. Microelectronic Engineering 84: 2336-2339.

Ngai, T., Qi, W.J., Sharma, R., Fretwell, J., Chen, X., Lee, J.C. \& Banerjee, S. 2000. Electrical properties of $\mathrm{ZrO} 2$ gate dielectric on SiGe. Appl. Phys. Lett. 76: 502-504.

van Elshochta, S., Caymax, M., Conard, T., De Gendt, S., Hoflijk, I., Houssa, M., De Jaeger, B., van Steenbergen, J., Heyns, M. \& Meuris, M. 2006. Effect of hafnium germanate formation on the interface of HfO2/germanium metal oxide semiconductor devices. Appl. Phys. Lett. 88: 141904.

Wang, S.Q. \& Mayer, J.W. 1988. Reactions of Zr thin films with SiO2 substrates. J. Appl. Phys. 64(9): 4711.

Wallace, R.M., McIntyre, P.C., Kim, J. \& Nishi, Y. 2009. Atomic layer deposition of dielectrics on Ge and III-V materials for ultrahigh performance transistor. MRS Bull. 34(7): 493-503.

Wu, D., Lu, J.E., Vainonen-Ahlgren, E., Tois, M., Tuomine, M., Östling, M. \& Zhang, S.L. 2005. Structural and electrical characterization of $\mathrm{Al} 2 \mathrm{O} 3 / \mathrm{HfO} / \mathrm{Al} 2 \mathrm{O} 3$ on strained $\mathrm{SiGe}$. Solid-State Electronics 49(2): 193-197.

Zhang, L., Li, H., Guo, Y., Tang, K., Woicik, J., Robertson, J. \& McIntyre, P.C. 2015. Selective passivation of $\mathrm{GeO} 2 / \mathrm{Ge}$ interface defects in atomic layer deposited High-k MOS structures. Appl. Materials and Interface 7(37): 20499-20506.

Zhang, R., Huang, P.C., Lin, J.C., Teoka, N. \& Takenaka, M. 2013. High-mobility Ge p- and n-MOSFETs with $0.7-\mathrm{nm}$ EOT using $\mathrm{HfO} 2 / \mathrm{Al} 2 \mathrm{O} 3 / \mathrm{GeOx} / \mathrm{Ge}$ gate stacks fabricated by plasma postoxidation. IEEE Transactions on Electron Devices 60: 927-934.

Zhao, J., Yang, L., McLeod, A.J. \& Liu, L. 2015. Reduced $\mathrm{GeO} 2$ nanoparticles: Electronic structure of a nominal GeOx complex and its stability under H2 annealing. Scientific Reports 5:1-10.

Siti Kudnie Sahari*, Nik Amni Fathi Nik Zaini Fathi, Norsuzailina Mohamed Sutan, Muhammad Kashif, Marini Sawawi, Rohana Sapawi, Kuryati Kipli, Abdul Rahman Kram \& Nazreen Junaidi Faculty of Engineering

Universiti Malaysia Sarawak

94300 Kota Samarahan, Sarawak

Malaysia

Azrul Azlan Hamzah

Institute of MicroEngineering and Nanotechnology

Universiti Kebangsaan Malaysia

43600 UKM Bangi, Selangor Darul Ehsan

Malaysia

Zaidi Embong

Faculty of Science

Technology and Human Development

Universiti Tun Hussein Onn Malaysia

86400 Parit Raja, Batu Pahat, Johor Darul Takzim

Malaysia

Suhana Mohamed Sultan

Department of Electronic and Computer Engineering

Universiti Teknologi Malaysia

81310 Skudai, Johor Bahru, Johor Darul Takzim

Malaysia

Lilik Hasanah

Universitas Pendidikan Indonesia

Jl. Dr. Setiabudhi No 229, Bandung

Indonesia

*Corresponding author; email: sskudnie@unimas.my

Received: 14 August 2018

Accepted: 26 November 2018 